\title{
Critical Success Factors of the Intelligentization in Precision Machinery Industry
}

\author{
Wen-Hsiang Lai, Hsuan Chen \\ Feng Chia University \\ E-mail address whlai@,fcu.edu.tw ; E-mail address cutemilly100429@gmail.com
}

\begin{abstract}
Various industries related to daily life are related to the precision machinery industry (PMI). With the pace of Industry 4.0, PMI is one of the industries with great development potential. Renewal progress has not only caused changes in life but also revealed a significant impact on occupations. In recent years, the rise of Industry 4.0 has increased the output value of various industries. The launch of Industry 4.0 has led to global manufacturing initiatives to improve production efficiency and to reduce its burden. In order to increase its industrial benefit as the goal, it is important to discuss the problems and challenges that people face. Therefore, this study uses the Analytic Hierarchy Process (AHP) method to focus on the objectives of the research on the critical success factors of intelligentization in PMI. This study not only expects to provide the existing machinery manufacturing industry and the management policies for the future investment in PMI manufacturer reference value but also expects to serve as an academic reference for government policy considerations and scholars in the machinery manufacturing industry.
\end{abstract}

Keywords: Machinery manufacturing industry, Critical Success factors, Intelligentization, Industry 4.0

\section{INTRODUCTION}

This is an open access article under the CC-BY-NC license.

The machinery industry is the "mother of industry," and all related industries in daily life are closely related to the PMI, such as aircraft carriers at sea, cruise ships, yachts, large passenger planes in the sky, high-speed rails on the road, automobiles, etc. If such problems are not improved, the development of this industry is facing the fate of being eliminated. Therefore, the machinery industry is striving to integrate automation, and the main purpose of the PMI is to upgrade manufacturing. For the intelligent PMI, For smart PMI, this research hopes to extend to countries to cooperate and expand its market opportunities to increase industry value. In order to adapt to the changing needs of customers, the value definition of the entire product life cycle will be redefined. Industry 4.0 still has a vision.

It contains a realistic concept of the Internet of Things. Industry 4.0 focuses on the integration of people in the manufacturing process, brakes continuous improvement, and focuses on value-added activities to avoid wasteful waste, but the implementation of Industry 4.0 and it is the challenges and problems that will be encountered will be new trends in research (Vaidyaa et al., 2018).

In the existing industry, data processing and intelligence in the manufacturing process are most needed. Now, the machinery manufacturing industry is shifting from large-scale self-made production to customized production. And quickly improve its manufacturing technology and speed, and its application improves the performance of the industry. Sustainability issues have become one 
of the main challenges facing the industry today. New industries such as Industry 4.0 point to the creation of sustainable processes. However, the transition from traditional manufacturing to new Industry 4.0 manufacturers still needs time to observe. Put forward a series of obstacles that organizations must overcome to overcome some of the sustainable development challenges during the transition to Industry 4.0 (Paravizo et al., 2018).

Therefore, this study will take Industry 4.0 as the main concept and PMI as the research object and adopt Analytic Hierarchy Process as the research method to solve the solutions and the problems that are about to be faced, and then propose improvements to the problems to make the industry in The future can create a higher competitive advantage.

\section{LITERATURE REVIEW}

In order to improve production efficiency while reducing the cost of factories and increasing the value-added of their industries, governments of various countries have made major efforts to change their industries and promote economic growth. With smart factories as the main core, combining automation, the Internet of Things, and big data to form its Industry 4.0 architecture, smart factories can produce differentiated products on a large scale to meet the different needs of customers. Coupled with automated collaboration, it can reduce expenditure, improve production efficiency, and independently manage and improve (Ding Hong et al., 2018).

Currently, the industry most needs to digitize and intelligent its processes. And large-scale production is shifted to customized production. The rapid development of manufacturing technology and its effective application will help increase the productivity of the industry. Even though related mechanical products are continuously upgraded and updated, they still face fierce international competition in the industry 4.0 era (Rong Feng, 2015).

The fourth industrial revolution will be redefined by Industry 4.0. It is defined as the entire value chain of the product life cycle, which is adjusted to meet customer needs. Industry 4.0 is still far-sighted, which includes a realistic concept of the Internet of Things, industrial automation, smart manufacturing, and big data manufacturing. Industry 4.0 focuses on the integration of human-tomanufacturing processes in order to continuously improve and focus on value-added activities to avoid unnecessary waste. However, the implementation of Industry 4.0 and the challenges and problems encountered in it will be a new trend in research. (Vaidyaa et al., 2018).

Sustainability in the production process has become one of the main challenges facing the industry today. New industrial paradigms such as Industry 4.0 point to the creation of sustainable processes. However, the transition process from traditional manufacturing to Industry 4.0 manufacturers presents a series of obstacles that organizations must overcome to overcome some of their sustainable development challenges during the transition to Industry 4.0 (Paravizo et al., 2018). The vision of Industry 4.0 emphasizes that automated machines in a smart factory environment can be used in the Internet of Things, enabling a large amount of data to be able to exchange information and control each other autonomously. Also, because the cooperation between suppliers, manufacturers, and customers is essential to improve the transparency of all steps from the order delivery to the end of the product life cycle, it is necessary to analyze the impact of Industry 4.0 on manufacturing supply as a whole (Tjahjono et al., 2018).

Therefore, this study uses AHP to explore the aspects and indicators that Industry 4.0 emphasizes on the PMI's business model and evaluate the ranking and weighting of each aspect and indicators to integrate the PMI. This study explores the core aspects and indicators of the business model, and then through in-depth interviews to understand the current situation and perspectives of Industry 4.0 on Taiwan's PMI, hoping to provide a reference value for the existing machinery 
manufacturing industry and business decision-makers who want to invest in the machinery manufacturing industry in the future. This study also provides a government policy consideration and an academic reference for scholars in the machinery manufacturing industry.

\section{RESEARCH METHODOLOGY}

This study is based on the research background and research motives. It is hoped to make effective analysis and recommendations for the production planning of precision machines for Industry 4.0 and use the suggestions of past scholars to achieve the most efficient production capacity. The design of the research method in this study constructs the discussion of relevant literature and a research framework with theoretical and practicality in the literature, as well as the research motivation assessment. The research method of data analysis is explained; finally, the questionnaire design and sampling method are used to analyze the most effective production capacity scale and pass the expert validity review to provide suggestions for the key factors and indicators of intelligentization affecting the PMI.

Based on the literature discussion, a conceptual diagram of the research framework and various influencing factors (Figure1) were constructed, and four main aspects and eleven influential subaspects were collected.

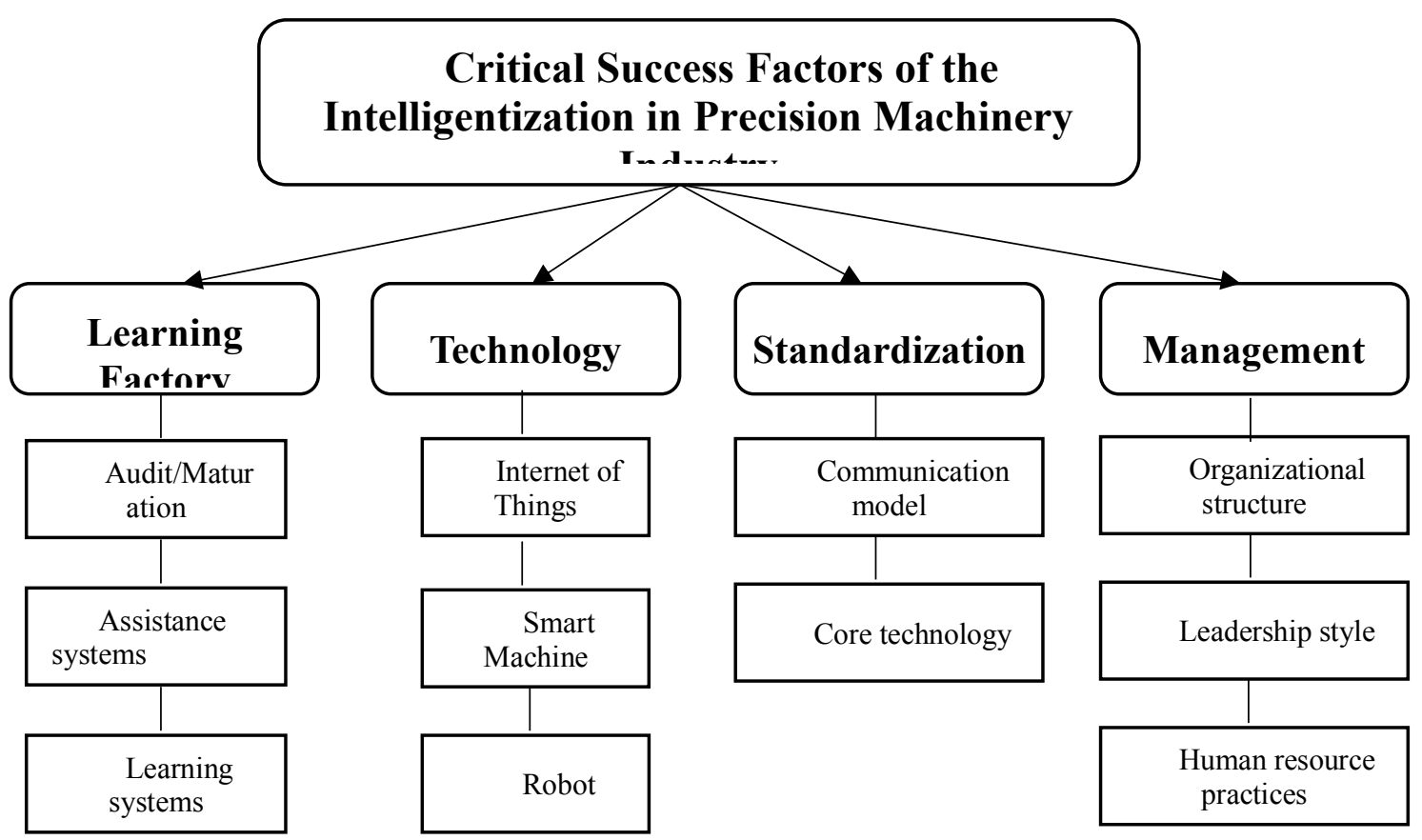

Figure1: Hierarchical Structure

\section{EXPECTED RESULTS}

Based on the literature discussion, this research summarizes the four main aspects of the key success factors that affect the critical success factors of the Intelligentization in Precision Machinery 
Industry and their corresponding eleven sub-factors and uses the definition of conduct to define the scope of their description (Tables 1 and Table 2).

Table 1. Four Influencing Factors of Critical Success Factors of the Intelligentization in Precision Machinery Industry

\begin{tabular}{|c|c|c|}
\hline Factor & Operational Definition & Literature Cited \\
\hline $\begin{array}{l}\text { Learning } \\
\text { Factory }\end{array}$ & $\begin{array}{l}\text { Under globalization and market volatility, the } \\
\text { manufacturing industry faces different situations, and } \\
\text { companies need to formulate for their employees, in the } \\
\text { future, they can quickly adapt to the environment and } \\
\text { specialize in professional training. }\end{array}$ & Kreimeier (2014) \\
\hline Management & $\begin{array}{l}\text { Industry } 4.0 \text { has flexible processes and high- } \\
\text { efficiency production. In order to enable employees to } \\
\text { work at the pace of Industry } 4.0 \text {, it provides an } \\
\text { atmosphere suitable for employee learning and } \\
\text { innovation. }\end{array}$ & Shamim (2016) \\
\hline Standardization & $\begin{array}{l}\text { When the manufacturing industry is transforming, it } \\
\text { is necessary to match its equipment, technology, and } \\
\text { processes so that the data can match and correspond to } \\
\text { each other, so that the manufacturing industry can find } \\
\text { problems in the product and service process. }\end{array}$ & $\begin{array}{l}\text { Igor (2016) } \\
\text { Parka (2016) }\end{array}$ \\
\hline Technology & $\begin{array}{l}\text { Connect and optimize customer needs, business } \\
\text { processes, production processes, products, equipment, } \\
\text { personnel, and supply chain technology. }\end{array}$ & Lin Wang (2017) \\
\hline
\end{tabular}

Table 2 Influences the sub-elements of Critical Success Factors of the intelligentization in Precision Machinery Industry

\begin{tabular}{|c|c|c|c|}
\hline Factor & $\begin{array}{l}\text { Sub- } \\
\text { factor }\end{array}$ & Operational Definition & $\begin{array}{l}\text { Literatur } \\
\text { e Cited }\end{array}$ \\
\hline \multirow{3}{*}{ Technology } & $\begin{array}{l}\text { Internet of } \\
\text { Things }\end{array}$ & $\begin{array}{l}\text { Use wireless technology to connect to the } \\
\text { network, connect customers and suppliers to } \\
\text { solve complex production processes. }\end{array}$ & $\begin{array}{l}\text { Igor } \\
(2016)\end{array}$ \\
\hline & $\begin{array}{r}\text { Smart } \\
\text { Machine }\end{array}$ & $\begin{array}{l}\text { It can calculate the information requested by } \\
\text { the customer and transmit the information to } \\
\text { related equipment, and the equipment can } \\
\text { transmit information to each other to achieve } \\
\text { accurate production. }\end{array}$ & $\begin{array}{l}\text { Jun, Yin } \\
\text { (2015) }\end{array}$ \\
\hline & Robot & $\begin{array}{l}\text { It will replace human beings in simple or } \\
\text { low-tech production. Robots, smart devices, } \\
\text { and humans will go hand in hand to } \\
\text { communicate with each other and exchange } \\
\text { data and produce with high flexibility. }\end{array}$ & $\begin{array}{l}\text { Andrzej } \\
\text { (2016) }\end{array}$ \\
\hline $\begin{array}{l}\text { Standardizati } \\
\text { on }\end{array}$ & $\begin{array}{r}\text { Communi } \\
\text { cation model }\end{array}$ & $\begin{array}{l}\text { Let devices that do not have the same } \\
\text { foundation implement CPS together, even } \\
\text { without the use of unified communication } \\
\text { specifications and physical media. }\end{array}$ & $\begin{array}{c}\text { Igor } \\
(2016)\end{array}$ \\
\hline
\end{tabular}




\begin{tabular}{|c|c|c|c|}
\hline & $\begin{array}{c}\text { Core } \\
\text { technology }\end{array}$ & $\begin{array}{l}\text { In order to determine the core value of a } \\
\text { company's products or services, formulate the } \\
\text { production process, inter-enterprise links, } \\
\text { product life cycle, and accurately collect the } \\
\text { required data. }\end{array}$ & $\begin{array}{l}\text { Parka } \\
\text { (2016) }\end{array}$ \\
\hline \multirow{3}{*}{ Management } & $\begin{array}{l}\quad \text { Organizat } \\
\text { ional } \\
\text { structure }\end{array}$ & $\begin{array}{l}\text { Under Industry } 4.0 \text {, companies must have } \\
\text { the ability to respond quickly and innovate. The } \\
\text { corporate structure will affect the effectiveness } \\
\text { of employee learning and the generation of } \\
\text { innovative ideas. Therefore, companies need to } \\
\text { develop their own and comply with Industry } \\
\text { 4.0. }\end{array}$ & $\begin{array}{l}\text { Tom } \\
\text { (1961) }\end{array}$ \\
\hline & $\begin{array}{l}\text { Leadershi } \\
\text { p style }\end{array}$ & $\begin{array}{l}\text { Leaders influence the skills of others, inspire } \\
\text { others, inspire others, and guide how to achieve } \\
\text { organizational goals. Under Industry } 4.0 \text {, a } \\
\text { dedicated leadership style is needed to } \\
\text { accelerate the process of employee innovation } \\
\text { and learning. }\end{array}$ & $\begin{array}{l}\text { Jones } \\
\text { (2003) }\end{array}$ \\
\hline & $\begin{array}{l}\text { Human } \\
\text { resource } \\
\text { practices }\end{array}$ & $\begin{array}{l}\text { Enterprises enable their employees to } \\
\text { achieve organizational goals with their skills, } \\
\text { abilities, behaviors, and attitudes. Enterprises } \\
\text { use corresponding designs to enhance their } \\
\text { employees' innovation ability, knowledge } \\
\text { management ability, and learning ability. }\end{array}$ & $\begin{array}{l}\text { Collins } \\
(2003) \\
\text { Donate } \\
(2018)\end{array}$ \\
\hline \multirow{3}{*}{$\begin{array}{l}\text { Learning } \\
\text { Factory }\end{array}$} & $\begin{array}{l}\text { Audit/Mat } \\
\text { uration }\end{array}$ & $\begin{array}{l}\text { It is an early stage. Before the } \\
\text { transformation, it is necessary to confirm the } \\
\text { core value of the company's products or services } \\
\text { and evaluate the current capabilities and future } \\
\text { development goals of the company and } \\
\text { employees and finally establish an evaluation } \\
\text { model. }\end{array}$ & $\begin{array}{l}\text { Kreimei } \\
\text { er (2014) }\end{array}$ \\
\hline & e $\begin{array}{c}\text { Assistanc } \\
\text { systems }\end{array}$ & $\begin{array}{l}\text { In order to accelerate the work efficiency of } \\
\text { employees, auxiliary systems and equipment } \\
\text { are required, such as tablet computers, smart } \\
\text { bracelets, etc. }\end{array}$ & $\begin{array}{l}\text { Kreimei } \\
\text { er (2014) }\end{array}$ \\
\hline & $\begin{array}{l}\text { Learning } \\
\text { systems }\end{array}$ & $\begin{array}{l}\text { Establish an integrated learning system that } \\
\text { combines the workplace to provide employees } \\
\text { with complete learning content and ensure their } \\
\text { competitiveness in the market. }\end{array}$ & $\begin{array}{l}\text { Kreimei } \\
\text { er (2014) }\end{array}$ \\
\hline
\end{tabular}

In the early days, PMI focused on mass production. In recent years, the rise of Industry 4.0 has promoted the output value of PMI and accelerated its transformation and development. However, it began to fail to meet expectations, and countries have begun to move towards smart production. Makes the development of PMI to face the inability to change and progress. Therefore, PMI is working hard to integrate the overall solution of automation and mechanical automation. With the rapid development of various high-tech technologies, we are facing the new fourth industrial revolution. Smart manufacturing has become a direction that must be followed up. 
In the manufacturing industry, data processing and intelligence in the manufacturing process are very important to PMI. It is worth mentioning that the machinery industry is turning to customized production and is rapidly improving its manufacturing technology and speed to increase productivity. In order to respond to changing customer needs, variability has become one of the main challenges in the production process. Therefore, this research will bring more competitive advantages to PMI through the upgrade and change of smart words.

\section{REFERENCES}

Andrzej Magruk (2016). Uncertainty in the sphere of the Industry 4.0 -Potential Areas to Research, ManageMent, and Education, 14(2), 275-291.

Collins CJ, Clark KD. (2003). Strategic human resource practices, top management team social networks, and firm performance: the role of human resource in creating organizational competitive advantage. Academy of Management Journal. Volume 46(6): 740-51.

Donate, M.J., \& de Pablo, J.D.S. (2018). The role of knowledge-oriented leadership in knowledge management practices and innovation. Management Science Letters, 8(3), 151-160.

Igor Halenár, Bohuslava Juhásová, \& Martin Juhás (2016). Design of a communication scheme in a modern factory in accordance with the standard of industry 4.0, Research papers, 24(39), 101109.

Jun Yin. (2015), The application of industry 4.0 in the aeronautical manufacturing industry. Manufacturing Automation, 37 (10), 5-5.

Jones, G.R., George, J.M., \& Hill, C.W. (2003). Contemporary management New York: McGrawHill/Irwin.

Kreimeier, D., Morlock, F., Prinz, C., Krückhans, B., Bakir, D. C., \& Meier, H. (2014). Holistic learning factories-A concept to train lean management, resource efficiency, as well as management and organization improvement skills. Procedia CIRP, 17, 184-188.

Lin Wang, Jinfeng He, Songjie Xu (2017). The Application of Industry 4.0 in Customized Furniture Manufacturing Industry, MATEC Web of Conferences 100, 1, 1-4.

Ting Hong, Chen、Yao Yu, Yang \& Zi Yi, Dong(2018). Patent Trend Analysis of Machine Tool Industry 4.0, Intellectual Property Rights Monthly, 229, 63-78.

Tjahjono, B., Esplugues, C., Ares, E., \& Pelaez, G. (2017). What does industry 4.0 mean to the supply chain? Procedia Manufacturing, 13, 1175-1182.

Tom burns, \& G.M. Stalker. (, 1961). The management of innovation. London, Tavistock.

Vaidyaa, S., Ambadb, P., \& Bhoslec, S. (2018). Industry 4.0-a glimpse. Design Engineering, Procedia Manufacturing 20, 233-238.

Paravizo, E., Chaim, O. C., Braatz, D., Muschard, B., \& Rozenfeld, H. (2018). Exploring gamification to support manufacturing education on industry 4.0 as an enabler for innovation and sustainability. Procedia Manufacturing, 21, 438-445.

Sungbum Parka (2016). Development of Innovative Strategies for the Korean Manufacturing Industry by Use of the Connected Smart Factory (CSF), ScienceDirect, 91, 744- 750.

Rong Feng, Zhong (2015). Silence pushes Taiwan's precision machinery to hold up the sky. Central News Agency. From http://tve.cna.com.tw/precisionmachinery_industry.aspx

Saqib Shamim, Shuang Cang, Hongnian Y1, Yun Li (2016). Management Approaches for Industry 4.0 A human resource management perspective, IEEE Congress on Evolutionary Computation (CEC), 6(16), 5309-5316. 